\title{
Nitrogen uptake by heterotrophic bacteria and phytoplankton in the nitrate-rich Thames estuary
}

\author{
Jack J. Middelburg*', Joop Nieuwenhuize
}

Netherlands Institute of Ecology, Korringaweg 7, 4401 NT Yerseke, The Netherlands

\begin{abstract}
The uptake of ammonium, nitrate, amino acids and urea was examined in the nitraterich Thames estuary and adjacent area in the North Sea during February 1999. The majority of uptake was by heterotrophic bacteria, as demonstrated by addition of a prokaryotic inhibitor that lowered uptake rates by $82,66,49$ and $86 \%$ for ammonium, nitrate, amino acids and urea, respectively. Amino acids were preferred over ammonium and urea, which in turn were preferred over nitrate. Urea was not important as nitrogen substrate. Amino acids were the main nitrogen substrate offshore and at the mouth of the estuary, but in the inner estuary nitrogen was mainly taken up as ammonium and, even more, as nitrate. Nitrate appeared to be the main substrate in the inner estuary (60 to $90 \%$ ) despite its low affinity for nitrate. The high nitrate uptake by heterotrophic bacteria is probably due to high ambient concentrations of nitrate (up to $650 \mu \mathrm{M}$ ).
\end{abstract}

KEY WORDS: Ammonium · Nitrate $\cdot$ Urea $\cdot$ Amino acids $\cdot$ Estuary $\cdot$ Nitrogen uptake $\cdot$ Heterotrophic bacteria Resale or republication not permitted without written consent of the publisher

\section{INTRODUCTION}

Estuaries are heterotrophic systems, with overall respiration, mainly bacterial, exceeding primary production (e.g. Heip et al. 1995, Gattuso et al. 1998). This heterotrophy of estuarine systems is sustained by the import of organic matter from the river and from lateral ecosystems such as marshes and the sea. Bacterial assimilation of nitrogen has been reported to account for a significant but variable ( $<5$ to $>90 \%$ ) fraction of total nitrogen uptake in estuarine and marine systems (e.g. Wheeler \& Kirchman 1986, Horrigan et al. 1988, Kirchman 1994, Hoch \& Kirchman 1995, Kirchman \& Wheeler 1998, Middelburg \& Nieuwenhuize 2000). Heterotrophic bacteria assimilate nitrogen because organic substrates often do not contain sufficient nitrogen to support bacterial growth completely. Quantification and understanding of bacterial nitrogen assimilation is not only important to studies of phytoplankton and bacterial dynamics, but has also implications for

*E-mail: middelburg@cemo.nioo.knaw.nl food web interpretations based on stable isotopes, since base-line signatures may be modified by bacterial processing (Caraco et al. 1998).

Most studies have focussed on ammonium and dissolved free amino acid uptake by heterotrophic bacteria (e.g. Kirchman 1994). The sum of ammonium and dissolved free amino acids often accounts for $>90 \%$ of bacterial $\mathrm{N}$ demand to support growth, and bacteria usually prefer dissolved free amino acids and ammonium over other nitrogen sources such as nitrate, urea and DNA (e.g. Wheeler \& Kirchman 1986, Keil \& Kirchman 1991, Jørgensen et al. 1993 1999, Kirchman 1994). Hoch \& Kirchman (1995) compiled evidence that ammonium uptake by bacteria is rather low (5 to $10 \%$ of total ammonium uptake) in estuaries with relatively high concentrations of dissolved free amino acids, but is higher in the mouth of estuary, the adjacent coastal waters, and oceanic systems as a consequence of lower concentrations of dissolved free amino acids in these regions. However, Hoch \& Kirchman were less successful in explaining variation within the Delaware estuary. Recently, Middelburg \& Nieuwenhuize (2000) presented evidence that bacteria accounted for $>90 \%$ 
of the ammonium uptake in the dark in the turbid Loire estuary, France.

Nitrate assimilation by heterotrophic bacteria has been documented (Horrigan et al. 1988, Lipschutz 1995), but has usually been ignored because it appears to be the least preferred nitrogen source (Wheeler \& Kirchman 1986, Kirchman et al. 1992). Recently, Kirchman \& Wheeler (1998) reported that heterotrophic bacteria accounted for 5 to $60 \%$ (average $32 \%$ ) of the total nitrate uptake in the sub-Arctic Pacific. They hypothesized that bacteria may take up significant amounts of nitrate at high ambient nitrate concentrations.

During the last few decades, concentrations of nitrate in rivers and estuaries have increased significantly through anthropogenic inputs. Nitrate concentrations $>1000 \mu \mathrm{M}$ have been reported in heavily populated areas such as the River Colne and Thames estuaries, United Kingdom (Nedwell et al. 1999). We hypothesize that these high concentrations of nitrate may cause uptake of nitrate by bacteria despite their low preference for this form of nitrogen. Caraco et al. (1998) incubated suspended matter from the Hudson estuary for a few months, and observed significant microbial assimilation of nitrate.

In this study, we report rates of ammonium, nitrate, dissolved free amino acids and urea uptake in the Thames estuary, a turbid, tidal, nitrate-rich system. The contribution of heterotrophic bacteria to nitrogen uptake was assessed through application of an antibiotic inhibitor. Our objectives were (1) to examine whether nitrate assimilation by heterotrophic bacteria is important in a high nitrate environment, (2) to determine whether bacteria account for most of the ammonium assimilation as observed in the turbid, tidal Loire estuary (Middelburg \& Nieuwenhuize 2000), or whether they contribute but little, as reported for the Delaware estuary and Chesapeake Bay (Kirchman 1994, Hoch \& Kirchman 1995).

\section{MATERIALS AND METHODS}

Thames estuary. The Thames estuary is a turbid, tidal estuary on the east coast of the United Kingdom, entering the North Sea at Southend-on-Sea (Kinniburgh 1998). The catchment has a surface area of $\sim 14000 \mathrm{~km}^{2}$ and hosts a population of more than 11 million, including London. The surface area of the inner estuary is $\sim 37 \mathrm{~km}^{2}$, the total length is $\sim 110 \mathrm{~km}$ and the tidal range varies from 3 to $6 \mathrm{~m}$. The input of freshwater may vary from $<10 \mathrm{~m}^{3} \mathrm{~s}^{-1}$ during times of drought to $>3500 \mathrm{~m}^{3} \mathrm{~s}^{-1}$ during winter, and averages $\sim 114 \mathrm{~m}^{3} \mathrm{~s}^{-1}$ (Kinniburgh 1998). The water residence time is in the order of $1 \mathrm{mo}$ but varies as a consequence of variability in freshwater discharge (Nedwell et al. 1999).
The River Thames is rich in nitrate, with concentrations sometimes exceeding $1 \mathrm{mM}$, and the load of dissolved inorganic nitrogen is $\sim 2.6 \times 10^{9} \mathrm{~mol} \mathrm{~N} \mathrm{yr}^{-1}$ (Nedwell et al. 1999). This corresponds to a nitrate export of $2600 \mathrm{~kg} \mathrm{~N} \mathrm{~km}{ }^{-2} \mathrm{yr}^{-1}$. Significant oxygen depletion (Kinniburgh 1998) and high partial pressures and effluxes of carbon dioxide (520 to 720 tons $\mathrm{C} \mathrm{d}^{-1}$; Frankignoulle et al. 1998) indicate that heterotrophic processes dominate over autotrophic processes in the Thames estuary.

Sampling. Water samples were collected during a cruise of the RV 'Belgica' in February 1999. Samples were collected at regular salinity intervals along the spine of the estuary from near the Millenium dome (Greenwich, London) to the open North Sea $\left(51^{\circ} 28^{\prime} 55^{\prime \prime} \mathrm{N}, 2^{\circ} 38^{\prime} 24^{\prime \prime} \mathrm{E}\right)$. Surface water (<2 m depth) samples were collected in 201 Niskin bottles and subsampled within $10 \mathrm{~min}$. Trace-metal cleaning techniques were not applied because of the polluted nature of the Thames estuary (Kinniburgh 1998).

Concentration measurements. Water samples were filtered immediately through pre-weighed, pre-combusted glass-fibre filters (GF/F, Whatman), stored frozen $\left(-20^{\circ} \mathrm{C}\right)$ and analysed within 2 wk for ammonium, nitrate and nitrite using automated colorimetric techniques. Dissolved free amino acids were analyzed by precolumn derivatization with o-phthalaldehyde and reverse-phase HPLC with fluorometric detection (Lindroth \& Mopper 1979, Dauwe \& Middelburg 1998). Urea was measured by colorimetry using the diacetylmonoxime reagent (Koroleff 1983).

The material on the filters was weighed and used for analyses of particulate carbon and nitrogen with a Carlo Erba NA 1500 Elemental analyser (Nieuwenhuize et al. 1994). The partial pressure of carbon dioxide in the surface water was measured while sailing and while on station using a shower-type equilibrator system coupled to a photo-acoustic analyzer (Bruel \& Kjaer Type 1302: Middelburg et al. 1996).

Nitrogen uptake rates. Water samples (50 to $200 \mathrm{ml}$ ) were spiked with $0.1 \mu \mathrm{mol} \mathrm{l} \mathrm{l}^{-1}{ }^{15} \mathrm{NH}_{4}, 1 \mu \mathrm{mol} \mathrm{l} \mathrm{l}^{-1}{ }^{15} \mathrm{NO}_{3}$, $0.1 \mu \mathrm{mol} \mathrm{l}{ }^{-1}{ }^{15} \mathrm{~N}$-Urea (Cambridge Isotope Laboratories NLM-233) and $0.1 \mu \mathrm{mol} \mathrm{l^{-1 }}$ of $>98 \%{ }^{15} \mathrm{~N}$-labelled algal amino-acid mixture (Cambridge Isotope Laboratories NLM-2161). Samples were incubated in $250 \mathrm{ml}$ bottles in on-deck incubators with running estuarine water. Incubations lasted $\sim 2 \mathrm{~h}$ and were performed in the dark and under ambient light on the deck of the ship without replication. Filtration of sample through precombusted Whatman GF/F filters (20 mm) was used to stop ${ }^{15} \mathrm{~N}$ incubations and was always completed within 5 min. The filters were immediately placed in aluminium foil and then stored frozen.

The at. $\%{ }^{15} \mathrm{~N}$ of freeze-dried filters was determined using a Fisons NA 1500 elemental analyzer coupled to 
a Finnigan Delta S mass spectrometer via a Conflo II interface. Specific uptake rate $\left(V, \mathrm{~h}^{-1}\right)$ was calculated according to Dugdale \& Wilkerson (1986) and was multiplied by the independently measured particulate nitrogen (PN) concentration to obtain the transport or absolute uptake rate $U$, $\left(\mu \mathrm{mol} \mathrm{N}^{-1} \mathrm{~h}^{-1}\right)$. Uptake rates were corrected for isotope dilution by means of the model of Kanda et al. (1987), whereby regeneration equalled uptake. Correction factors were always $<0.01,<1$, $<10$ and $<2 \%$ for ammonium, nitrate, amino acid and urea uptake, respectively.

The contribution of bacterial assimilation was estimated from the inhibition of substrate uptake in the dark. A broad-spectrum antibiotic (penicillin-G, streptomycin and neomycin; SIGMA, P3664), an inhibitor of cell growth of Gram-positive and Gramnegative bacteria, was added $2 \mathrm{~h}$ before the ${ }^{15} \mathrm{~N}$-tracers and at a final concentration of $10 \mathrm{mg} \mathrm{l}^{-1}$.

Analysis of variance (ANOVA) based on log-transformed data was used to evaluate significant differences. Post-hoc Tukey-Kramer tests were used to evaluate differences in RPI (relative preference index) ratios among substrates. Errors were propagated using the square root of the sumof-squares technique assuming independence of errors.

\section{RESULTS}

\section{Concentration measurements}

Although water temperatures ranged from 4.9 to $7^{\circ} \mathrm{C}$, there was substantial biological activity, as reflected in partial pressure of carbon dioxide $\left(\mathrm{pCO}_{2}\right)$ values ranging from $340 \mu \mathrm{atm}$ in the North Sea to $>2800 \mu$ atm in the upper estuary (Fig. 1A). Nitrate concentrations ranged from $>600 \mu \mathrm{M}$ in the river to $\sim 7 \mu \mathrm{M}$ in the North Sea. Ammonium concentrations in the River Thames and near London are high (30 to $43 \mu \mathrm{M})$, but decrease rapidly with increasing salinity (Fig. 1B). Nitrite concentrations were high in the upper estuary (4.8 to $8.1 \mu \mathrm{M})$, and decreased with increas- ing salinity (Fig. 1C). Concentrations of dissolved free amino acids and urea averaged $0.4 \pm 0.1 \mu \mathrm{M}$ (range 0.03 to $0.9 \mu \mathrm{M}$ ) and $0.69 \pm 0.08 \mu \mathrm{M}$ (range 0.18 to $1.2 \mu \mathrm{M})$, respectively, and showed no relation to salinity (Fig. 1C). Suspended matter concentrations ranged from $\sim 5$ to $220 \mathrm{mg} \mathrm{l}^{-1}$ and particulate nitrogen (PN) and organic carbon (POC) varied from 3 to 76 and 33 to
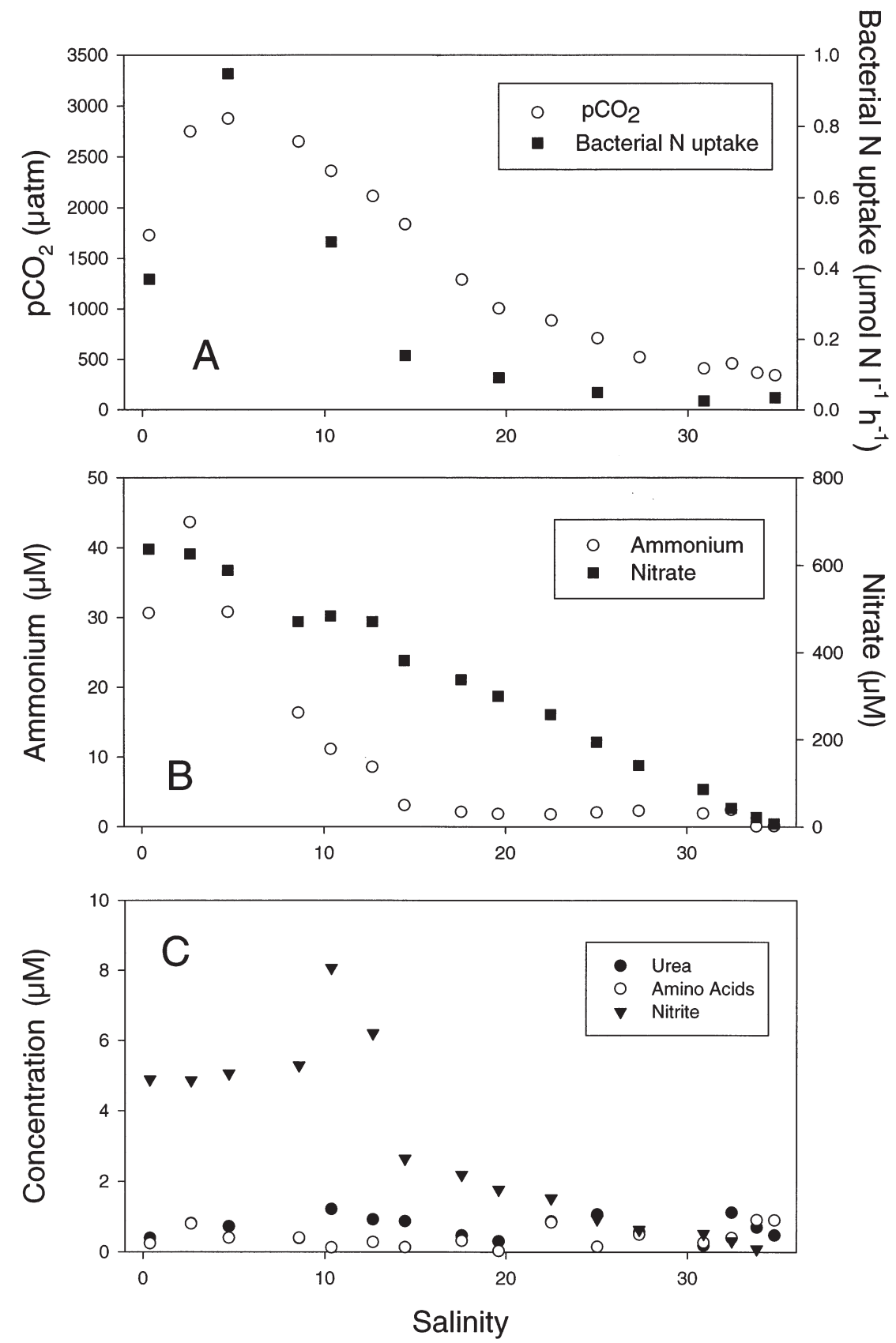

Fig. 1. (A) Partial pressure of carbon dioxide $\left(\mathrm{pCO}_{2}\right)$ and nitrogen uptake by heterotrophic bacteria (i.e. antibiotic-sensitive, dark, total nitrogen uptake) as a function of salinity; (B) concentration of ammonium and nitrate as a function of salinity; (C) concentration of urea, dissolved amino acids and nitrite as a function of salinity 
$700 \mu \mathrm{M}$, respectively, with maximum concentrations in the upper estuary. Chlorophyll a concentrations ranged from 0.9 to $2.9 \mu \mathrm{g} \mathrm{l}^{-1}$ (R. Wollast pers. comm.). Algal carbon (based on a C:chlorophyll a ratio of 40) contributed only a small fraction (range 1 to $11 \%$; average $4.9 \%$ ) to total POC. nium $(p=0.00017)$ and urea $(p=0.00017)$ uptake (Fig. 4), and RPI values for nitrate uptake were significantly lower than those for amino acids ( $p=0.00017)$, ammonium ( $p=0.00017)$ and urea $(p=0.00022)$.

Turnover of PN (PN divided by total $\mathrm{N}$ uptake) ranged from 0.7 to $9 \mathrm{~d}$, which was much shorter than the residence time of water in the Thames estuary.

\section{Nitrogen uptake}

Uptake rates of ammonium, nitrate and amino acid ranged from 0.003 to 0.42 , 0.001 to 1.44 and 0.006 to $0.15 \mu \mathrm{mol} \mathrm{N} \mathrm{^{-1 }}$ $\mathrm{h}^{-1}$, respectively (Fig. 2), and depended on salinity $(F=62.7, \mathrm{p}<0.00001 ; F=24.9$, $\mathrm{p}<0.00001, F=5.1, \mathrm{p}<0.01$, respectively). Rates of urea uptake were rather

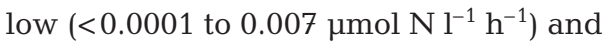
independent of salinity. Uptake rates in the light were not significantly different from those in the dark for all substrates except, perhaps, ammonium $(F=3.7, \mathrm{p}=$ 0.067).

Ammonium and nitrate uptake was highest in the upper estuary, whereas uptake of amino acids was maximal in the North Sea. Nitrate was the main substrate assimilated in the inner estuary (Fig. 3A). Ammonium contributed 15 to $30 \%$ in the low-salinity zone with high ammonium concentrations, and 10 to $20 \%$ in the mouth of the estuary, with lower contributions between these 2 areas. The contribution of urea was low $(<3 \%)$ compared to that of the other substrates. Amino acids constituted the main substrate in the North Sea, and their contribution decreased in an upstream direction (Fig. 3A). The high contribution of nitrate to total nitrogen uptake, corresponding to f-ratios of 0.6 to 0.9 in the inner estuary, was not related to dissolved ammonium concentrations.

The relative use of nitrogen substrates is often expressed in terms of the RPI (McCarthy et al. 1977), defined as:

$$
\begin{aligned}
\mathrm{RPI}_{X}= & {\left[U_{X} /\left(U_{\mathrm{NO}_{3}}+U_{\mathrm{NH}_{4}}+U_{\text {urea }}+U_{\text {amino acid }}\right)\right] / } \\
& {\left[X /\left(\mathrm{NO}_{3}+\mathrm{NH}_{4}+\text { urea }+ \text { amino acid }\right)\right] }
\end{aligned}
$$

where $\mathrm{RPI}_{X}=$ preference index of substrate $x_{r} U_{x}=$ uptake rate of substrate $x_{r}$ and $X=$ concentration of substrate $x$. RPI values for amino acid uptake were significantly higher than those for ammo-
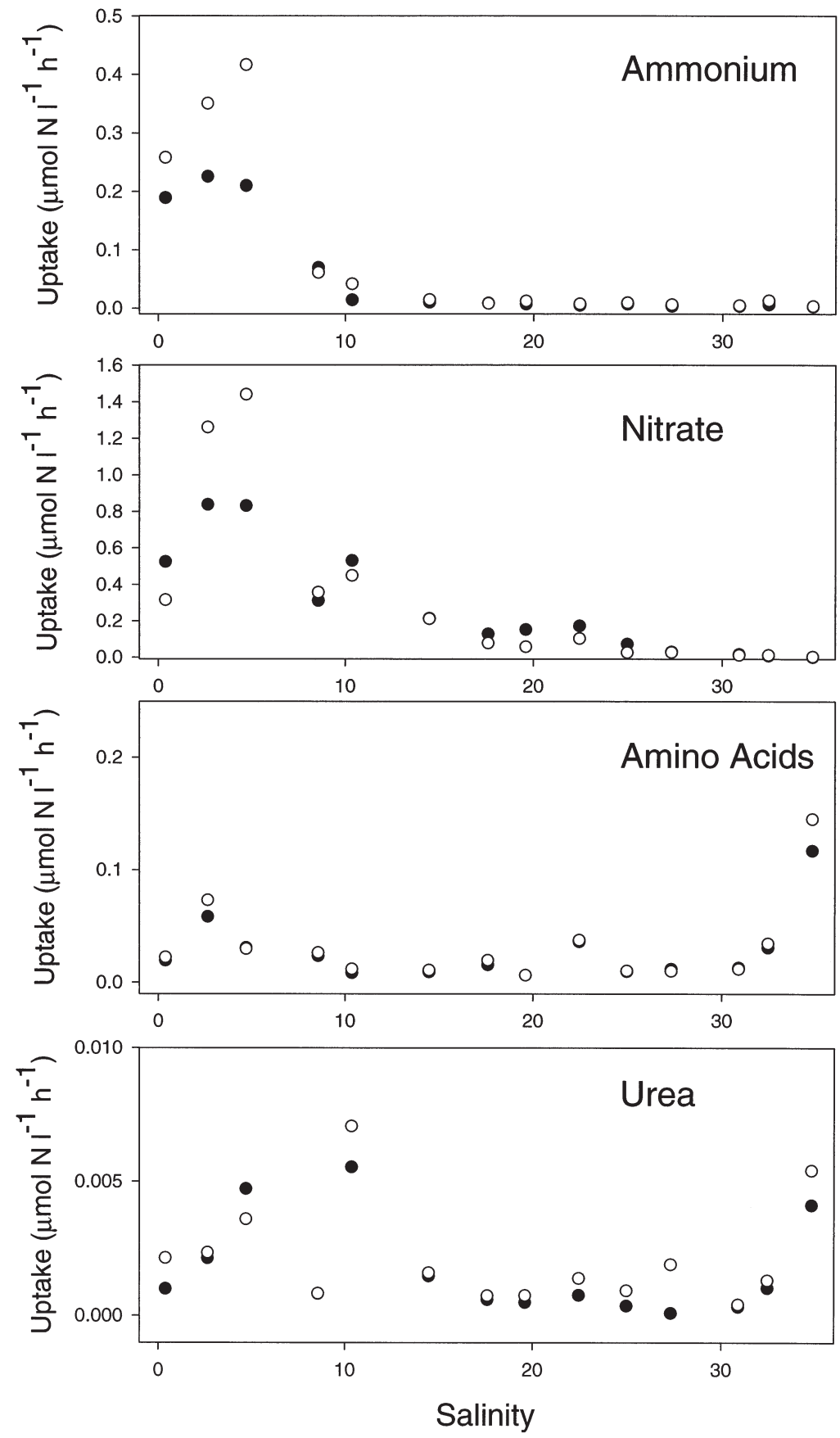

Fig. 2. Uptake rates of ammonium, nitrate, amino acids and urea as a function of salinity. (•) Dark uptake; (O) light uptake 

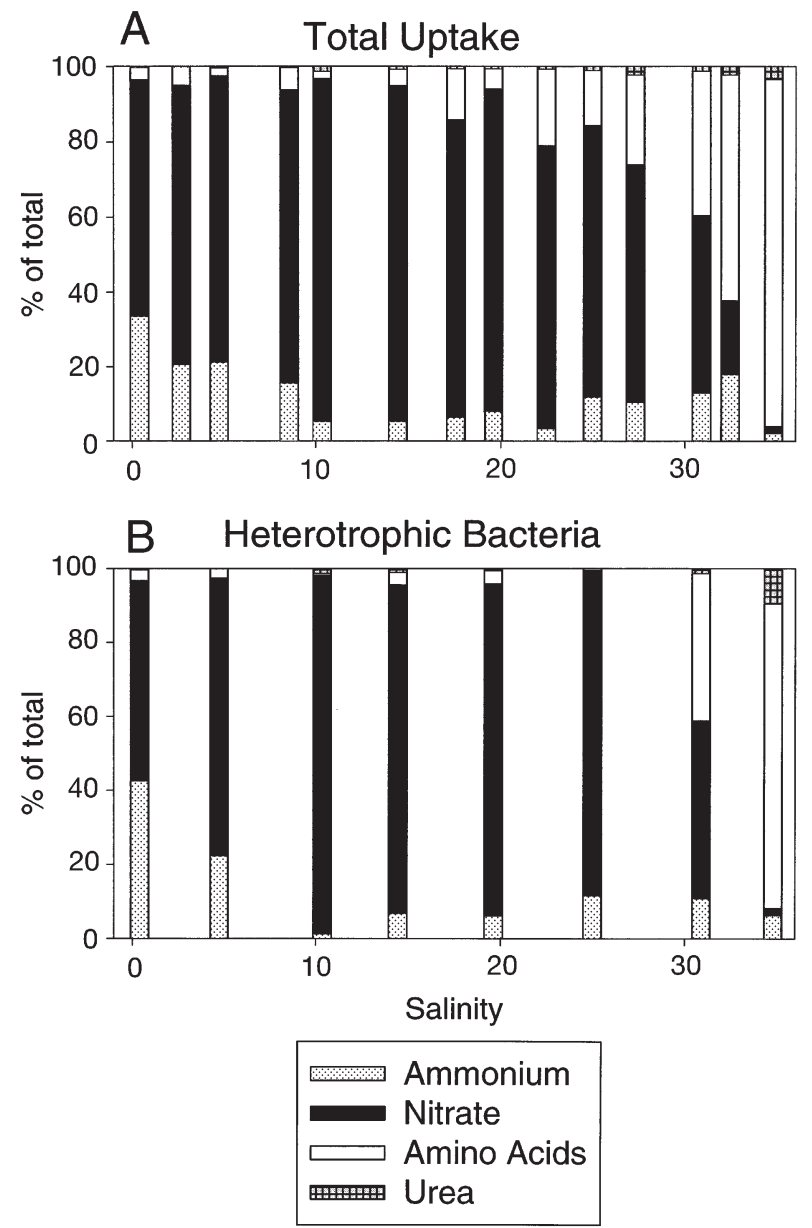

Fig. 3. Contribution of each of 4 nitrogen sources to total nitrogen uptake along salinity gradient. (A) Total uptake; (B) heterotrophic bacteria (i.e. antibiotic-sensitive nitrogen uptake)

Turnover rates of the nitrogen substrates (concentration divided by uptake rate) varied from 1.4-20, 22-232, 0.2-1.9 and 4.2-69 d for ammonium, nitrate, amino acids and urea, respectively.

\section{Bacterial contribution}

Addition of the antibiotic lowered uptake rates in the dark by $82 \pm 20,66 \pm 16,49 \pm 20$ and $86 \pm 25 \%$ for ammonium, nitrate, amino acid and urea uptake, respectively. (Fig. 5). The total nitrogen assimilation by heterotrophic bacteria ranged from 0.02 to $0.95 \mu \mathrm{mol} \mathrm{N}$ $\mathrm{l}^{-1} \mathrm{~h}^{-1}$, with highest rates in the upper estuary (Fig. 1A). Rates of bacterial assimilation were significantly correlated with the partial pressure of carbon dioxide $\left(\mathrm{r}^{2}=\right.$ $0.81, \mathrm{n}=8)$ and oxygen consumption rates $\left(\mathrm{r}^{2}=0.91\right.$, $\mathrm{n}=8$; data not shown).

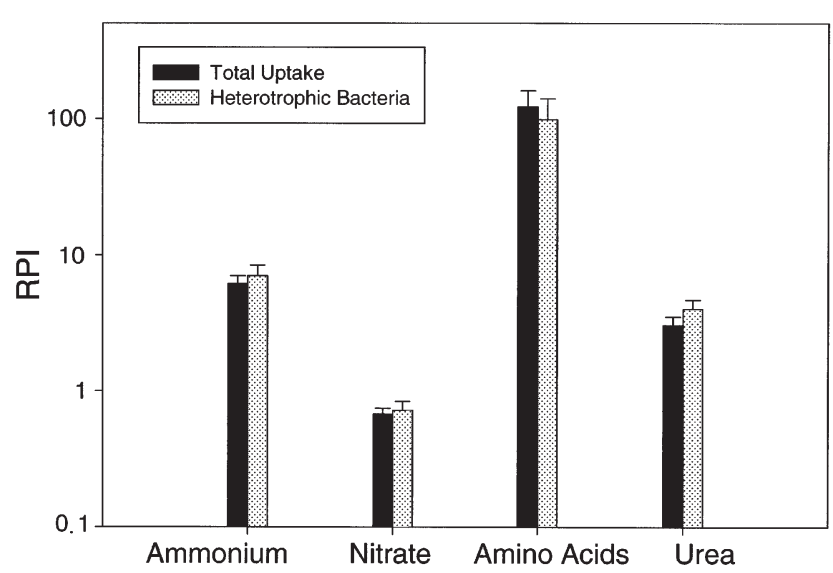

Fig. 4. Relative preference index (RPI) for each of 4 nitrogen sources for total uptake and antibiotic-sensitive uptake in the dark (heterotrophic bacteria)

Nitrate was the main substrate used by heterotrophic bacteria in the inner estuary (Fig. 3B), with ammonium contributing up to $40 \%$ in the River Thames. Amino acids were the major nitrogen substrate for heterotrophic bacteria in the North Sea and the mouth of the estuary. RPI values for the heterotrophic bacteria were similar to those for the total nitrogen-assimilating community, with amino acids $>\mathrm{NH}_{4} \approx$ urea $>\mathrm{NO}_{3}$ (Fig. 4).

\section{DISCUSSION}

\section{Nitrogen uptake in estuarine systems}

Before discussing in detail the dominant role of heterotrophic bacteria in nitrogen assimilation, it is instructive to compare nitrogen uptake in the Thames estuary with that in other estuarine systems. Our data represent winter conditions, whereas most literature data are for spring to fall. Moreover, our study is limited to ammonium, nitrate, amino acids and urea, while nitrite may be a significant substrate as well (Fig. 1C). Uptake rates of ammonium, nitrate and amino acids (Fig. 2) are in the range reported for other estuaries (McCarthy et al. 1977, Wheeler \& Kirchman 1986, Pennock 1987, Boyer et al. 1994, Shaw et al. 1998, Middelburg \& Nieuwenhuize 2000). However, our rates of urea uptake are in the lower range of the literature estimates (McCarthy et al. 1977, Carpenter \& Durham 1985, Shaw et al. 1998). Turnover of particulate nitrogen pools ( 0.7 to $9 \mathrm{~d}$ ) is similar to that observed in other turbid, tidal estuaries ( 0.7 to $31 \mathrm{~d}$; Middelburg \& Nieuwenhuize 2000), and shorter than the residence time of water in the Thames estuary $(\sim 1 \mathrm{mo})$. Suspended particles are consequently extensively modified during transit through the estuary. Turnover times 
of amino acids are very short $(<2 \mathrm{~d})$, consistent with literature data $(<2 \mathrm{~d}$; Hoch \& Kirchman 1995, Jørgensen et al. 1999). Turnover times of nitrate ( 22 to $232 \mathrm{~d}$ ) are within the range reported for other nitrate-rich turbid, tidal estuaries (19 to 2160 d; Middelburg \& Nieuwenhuize 2000) and similar to and larger than the residence time of water in the Thames estuary. Turnover times of ammonium (1.4 to 20) are similar to those reported for other tidal estuaries (0.1 to $27 d_{\text {i }}$ Middelburg \& Nieuwenhuize 2000) and smaller than or similar to the water residence time, indicating efficient recycling of ammonium. The turnover of the urea pool (4.2 to $69 \mathrm{~d}$ ) is within the wide range of other estuaries (3 to $>500 d_{\text {i }}$ Bronk et al. 1998, Shaw et al. 1998).

A number of studies have shown that nitrogenuptake rates in the dark may approach those in the light (Fisher et al. 1982, Pennock 1987, Boyer et al. 1994, Shaw et al. 1998), in particular during the winter season when algal biomass is low (Glibert \& Garside 1992, Middelburg \& Nieuwenhuize 2000). Consistently, ANOVA revealed that there was no detectable light effect on nitrogen uptake in the Thames estuary in February 1999. These high uptake rates in the dark have been attributed to phytoplankton uptake to balance growth over the diel cycle (e.g. Fisher et al. 1982, Pennock 1987, Glibert \& Garside 1992) and assimilation by heterotrophic bacteria (Eppley et al. 1977, Kirchman 1994, Middelburg \& Nieuwenhuize 2000).

Partitioning nitrogen uptake between phytoplankton and heterotrophic bacteria in turbid estuaries is difficult, because size fractionation by pre- or postincubation filtration is not feasible because of high concentrations of suspended matter that clog filters and the tight association of bacteria with these particles. Particle separation with flow cytometry (Lipschutz 1995) will probably be confronted with similar problems in turbid systems. Although metabolic inhibitors may suffer from a lack of specificity or incomplete inhibition (Oremland \& Capone 1988, Lee et al. 1992), they seem to have been applied with success in partitioning nitrogen assimilation into bacterial and autotrophic components (e.g. Wheeler \& Kirchman 1986, Middelburg \& Nieuwenhuize 2000). Wheeler \& Kirchman (1986) applied chloramphenicol, an inhibitor of prokaryotic protein synthesis, and observed that bacteria accounted for $>58 \%$ of the amino acid uptake and $>25 \%$ of the total ammonium uptake in coastal waters off Georgia and in the Gulf Stream. Middelburg \& Nieuwenhuize (2000) applied a broad-spectrum antibiotic that inhibits cell growth of Gram-positive and Gram-negative bacteria and observed an average inhibition of $93 \%$ for dark ammonium uptake in the Loire

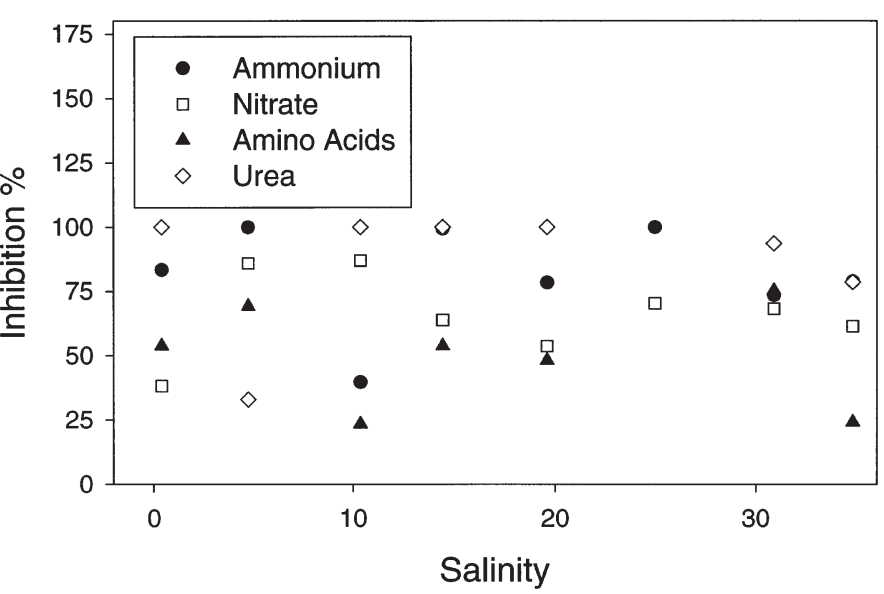

Fig. 5. Percentage dark uptake of ammonium, nitrate, amino acids and urea inhibited by antibiotic treatment, as a function of salinity

estuary. Consistently, addition of the broad-spectrum antibiotic to samples from the Thames estuary lowered uptake rates by an average of $82,66,49$ and $86 \%$ for ammonium, nitrate, amino acids and urea, respectively (Fig. 5). This strong inhibitory effect of the antibiotic on nitrogen uptake suggests that heterotrophic bacteria are dominating nitrogen assimilation in the Thames estuary, at least in the winter when phytoplankton biomass is low and algal growth is limited due to low light availability. Our inhibitor-based partitioning into phytoplankton and bacterial components of nitrogen uptake would probably underestimate the bacterial contribution if a fraction of the bacterial community were resistant and might overestimate the bacterial contribution if a fraction of eukaryotes were sensitive or if cyanobacteria were important in nitrogen uptake. Detailed pigment analysis by HPLC showed that cyanobacteria were not important in the Thames estuary (E. Lemaire pers. comm.). Moreover, the total nitrogen uptake rate of the antibiotic-sensitive bacterial community showed an excellent correlation $\left(\mathrm{r}^{2}=0.81\right)$ with the partial pressure of carbon dioxide, a measure of heterotrophic activity (Fig. 1A), indicating that heterotrophic bacteria dominated the antibiotic-sensitive community. The relatively low fraction of amino acid uptake $(\sim 50 \%)$ affected by the antibiotic treatment is surprising, since bacteria usually account for all amino acid uptake (Hoch \& Kirchman 1995). However, phytoplankton possess amino acid oxidases and may utilise the $\mathrm{N}$ of the amino acids (Palenik \& Morel 1990).

\section{Nitrogen substrate use}

The RPI compares the uptake of a substrate to total uptake relative to the fraction of that substrate to total 
nitrogen substrates (Fig. 4). The RPI should be used with care, because this complex ratio is difficult to interpret and is only weakly related to physiological preferences (e.g. Dortch 1990, Underwood \& Kromkamp 1999). Average RPI values for amino acids (99 to 122) are significantly higher than those for ammonium (6.1 to 7 ), urea ( 3 to 4 ) and nitrate (0.67 to 0.72$)$. The differences in RPI between nitrate on the one hand and the other N substrates on the other hand may be a consequence of the mathematical procedure and high nitrate concentrations (Stolte \& Riegman 1996), but the differences in RPI among amino acids, urea and ammonium are probably related to physiological preferences. The preference of the total assimilating community and heterotrophic bacteria for different nitrogen substrates is rather similar: amino acids > ammonium $\approx$ urea $>$ nitrate (Fig. 4). This similarity of RPI values for total and bacterial uptake is due to the dominant contribution of heterotrophic bacteria to total assimilation. This preference is similar to that reported in a number of other estuarine studies. McCarthy et al. (1977) reported that microbial communities in the Chesapeake Bay have a slight preference for ammonium relative to urea and that nitrate is the least preferred substrate. The relative uptake of ammonium and nitrate has been investigated in many estuaries, and it appears that ammonium is usually preferred over nitrate (for a recent review see Underwood \& Kromkamp 1999). Wheeler \& Kirchman (1986) studied nitrogen uptake by the fraction $<1 \mu \mathrm{m}$ (dominated by heterotrophic bacteria) at about equal substrate concentrations. They observed that amino acids were preferred over ammonium and that uptake of nitrate and urea was negligible. This preference sequence has been confirmed for heterotrophic bacteria in the Delaware estuary and adjacent coastal waters (Kirchman et al. 1992, Hoch \& Kirchman 1995), in the subArctic Pacific (Kirchman \& Wheeler 1998) and in seawater cultures derived from the Gulf of Mexico and Santa Rosa Sound (Jørgensen et al. 1999).

Urea contributed negligibly to total nitrogen uptake in the inner estuary, but contributed $\leq 9 \%$ to bacterial uptake in the North Sea (Fig. 3). This low contribution of urea to total nitrogen utilisation may appear inconsistent with some literature studies that indicated urea to be an important substrate $(20 \%$ in Chesapeake Bay: McCarthy et al. 1977; 70 to $80 \%$ in the plume of Chesapeake Bay during winter and summer: Glibert et al. 1991), but it is consistent with observations in the North Sea (10\% during spring: Riegman et al. 1998). This may be attributable to the low concentration of urea $(0.69 \pm 0.08 \mu \mathrm{M})$ relative to ammonium and nitrate in the Thames estuary (Fig. 1B) and the low temperature of the water (Lomas \& Glibert 1999). Although amino acids are the preferred substrate
(Fig. 4), they contribute little to nitrogen uptake in the inner estuary because of being present only in low concentrations $(0.4 \pm 0.1 \mu \mathrm{M})$. Amino acids were the main nitrogen substrate in the North Sea, and contributed about half of the total $\mathrm{N}$ uptake in the mouth of the estuary (Fig. 3). In the ammonium-rich, lowsalinity region of the Thames estuary, ammonium contributed 15 to $30 \%$ to total nitrogen uptake and 20 to $40 \%$ to uptake by heterotrophic bacteria. Ammonium contributed little in the North Sea (2\% to total uptake and $\sim 6 \%$ to bacterial $\mathrm{N}$ uptake), and $\sim 5$ to $20 \%$ in the other reaches of the estuary. The spatial distributions of ammonium and amino acid contributions are probably related to their relative in situ concentrations (Hoch \& Kirchman 1995). Amino acids constituted the main nitrogen substrate in the North Sea because concentrations of ammonium $(\sim 0.1 \mu \mathrm{M})$ and nitrate $(\sim 7 \mu \mathrm{M})$ were relatively low and those of amino acids relatively high ( 0.9 $\mu \mathrm{M}$; Fig. 1). Amino acid contributions were lower in an upstream direction because of increasing nitrate and ammonium concentrations (Fig. 1B).

Despite the low preference for nitrate, this was the main nitrogen substrate utilised in the inner estuary (Fig. 3), not only by the entire pelagic community, but also by the heterotrophic bacteria. Nitrate assimilation by heterotrophic bacteria has been documented before (Horrigan et al. 1988, Kirchman et al. 1992, Kirchman 1994, Lipschutz 1995, Kirchman \& Wheeler 1998, Jørgensen et al. 1999), but its ecological relevance is still not well understood. Stark \& Hart (1997) presented convincing evidence that the soil microbial community can assimilate almost all nitrate produced provided that microbial turnover is high. Kirchman et al. (1994) reported that bacteria accounted for 4 to $14 \%$ of total nitrate uptake in the North Atlantic during a spring bloom. Kirchman \& Wheeler (1998) observed that heterotrophic bacteria contributed 5 to $60 \%$ (mean of $32 \%$ ) to total uptake of nitrate in the rich sub-Arctic Pacific, where nitrate concentrations are relatively high (6 to $20 \mu \mathrm{M})$. These studies clearly revealed the importance of nitrate assimilation by heterotrophic bacteria, but our observation that nitrate is the most important nitrogen substrate utilised by heterotrophic bacteria is remarkable, and requires further study. These high nitrate-uptake rates are probably due to the high ambient concentrations of nitrate (up to $650 \mu M_{i}$ Fig. 1B), because the preference for nitrate, as reflected in the RPI, is not high (Fig. 4). The relative importance of nitrate assimilation by bacteria and dissimilatory nitrate reduction by bacteria in estuarine nitrate turnover is unknown, and our study does not provide enough data to evaluate this.

Significant assimilation of nitrate is expected in environments with high inputs of organic matter with a high $\mathrm{C}: \mathrm{N}$ ratio, high bacterial turnover rates, and high 
concentrations of nitrate relative to preferred substrates such as ammonium and amino acids. Heterotrophic, DOC and nitrate-rich systems such as the Thames (this study) and Hudson (Caraco et al. 1998) estuaries and marine sediments (Blackburn et al. 1996) are therefore expected to show significant nitrate assimilation. Caraco et al. (1988) suggested that microbial assimilation of nitrate might explain the negative correlation between the $\mathrm{C}: \mathrm{N}$ ratio of dissolved organic carbon and dissolved nitrate concentration.

Nitrogen-uptake patterns in the Thames estuary and other nitrate-rich, turbid estuaries in western Europe (Middelburg \& Nieuwenhuize 2000) show some similarities to and differences from the well-studied estuaries along the east coast of the USA such as the Chesapeake and Delaware estuary (McCarthy et al. 1977, Pennock 1987, Glibert et al. 1991, Glibert \& Garside 1992, Kirchman 1994, Hoch \& Kirchman 1995). In most estuaries, ammonium is preferred over nitrate, and there is significant uptake in the dark. However, bacteria account for most of the inorganic nitrogen uptake in European estuaries (Fig. 3, and Middelburg \& Nieuwenhuize 2000), whereas they contribute $<10 \%$ to the ammonium uptake in the Chesapeake and Delaware estuary (Kirchman 1994, Hoch \& Kirchman 1995). These differences in bacterial contributions to $\mathrm{N}$ uptake are probably due to differences in bacteriaphytoplankton community structures and availability of ammonium and nitrate. The macro-tidal, turbid estuaries in western Europe have a relatively low phytoplankton biomass because of light limitation and very high concentrations of nitrate (Fig. 1, and Nedwell et al. 1999, Middelburg \& Nieuwenhuize 2000), whereas concentrations of nitrate are lower and light availability better in the east coast estuaries of the USA (e.g. Lomas \& Glibert 1999).

Acknowledgements. We thank the commander and crew of the RV 'Belgica' for their hospitality, Michel Frankignoulle for his invitation to participate in the cruise, and our BIOGEST colleagues for sharing water samples and providing a pleasant, stimulating scientific climate. We thank Jacco Kromkamp, Peter Herman, Eric Boschker, Michel Frankignoulle and 4 anonymous reviewers for constructive remarks. This is Contribution No. 142 of the project BIOGEST to the EU-supported ELOISE programme (ENV4-CT96-0213) and publication number 2638 of the Netherlands Institute of Ecology, Yerseke.

\section{LITERATURE CITED}

Blackburn TH, Hall POJ, Hulth S, Landén A (1996) Organic$\mathrm{N}$ loss by efflux and burial associated with a low efflux of inorganic $\mathrm{N}$ and with nitrate assimilation in Arctic sediments (Svalbard, Norway). Mar Ecol Prog Ser 141: 283-293

Boyer JN, Stanley DW, Christian RR (1994) Dynamics of $\mathrm{NH}_{4}{ }^{+}$ and $\mathrm{NO}_{3}{ }^{-}$uptake in the water column of the Neuse River estuary, North Carolina. Estuaries 17:361-371

Bronk DA, Glibert PM, Malone TC, Banahan S, Sahlsten E (1998) Inorganic and organic nitrogen cycling in Chesapeake Bay: autotrophic versus heterotrophic processes and relationships to carbon flux. Aquat Microb Ecol 15: 177-189

Caraco NF, Lampman G, Cole JJ, Limburg KE, Pace ML, Fisher D (1998) Microbial assimilation of DIN in a nitrogen rich estuary: implications for food quality and isotope studies. Mar Ecol Prog Ser 167:59-71

Carpenter EJ, Dunham S (1985) Nitrogenous nutrient uptake, primary production, and species composition of phytoplankton in the Carmans River estuary, Long Island, New York. Limnol Oceanogr 30:513-526

Dauwe B, Middelburg JJ (1998) Amino acids and hexosamines as indicators of organic matter degradation state in North Sea sediments. Limnol Oceanogr 43:782-798

Dortch Q (1990) The interaction between ammonium and nitrate uptake in phytoplankton. Mar Ecol Prog Ser 61: 183-201

Dugdale RC, Wilkerson FP (1986) The use of ${ }^{15} \mathrm{~N}$ to measure nitrogen uptake in eutrophic oceans; experimental considerations. Limnol Oceanogr 31:673-689

Eppley RW, Sharp JH, Renger EH, Perry MJ, Harrison WG (1977) Nitrogen assimilation by phytoplankton and other microorganisms in the surface waters of the central North Pacific Ocean. Mar Biol 39:111-120

Fisher TR, Carlson PR, Barber RT (1982) Carbon and nitrogen primary productivity in three North Carolina estuaries. Estuar Coast Shelf Sci 15:621-644

Frankignoulle M, Abril G, Borges A, Bourge I, Canon C, Delille B, Libert E, Théate JM (1998) Carbon dioxide emission from European estuaries. Science 282:434-436

Gattuso JP, Frankignoulle M, Wollast R (1998) Carbon and carbonate metabolism in coastal aquatic ecosystems. Annu Rev Ecol Syst 29:405-434

Glibert PM, Garside C (1992) Diel variability in nitrogenous nutrient uptake by phytoplankton in the Chesapeake Bay plume. J Plankton Res 14:271-288

Glibert PM, Garside C, Fuhrman JA, Roman MR (1991) Timedependent coupling of inorganic and organic nitrogen uptake and regeneration in the plume of the Chesapeake Bay estuary and its regulation by large heterotrophs. Limnol Oceanogr 36:895-909

Heip CHR, Goosen NK, Herman PMJ, Kromkamp J, Middelburg JJ, Soetaert K (1995) Production and consumption of biological particles in temperate tidal estuaries. Oceanogr Mar Biol Annu Rev 33:1-150

Hoch MP, Kirchman DL (1995) Ammonium uptake by heterotrophic bacteria in the Delaware estuary and adjacent coastal waters. Limnol Oceanogr 40:886-897

Horrigan SG, Hagström ^̊, Koike K, Azam F (1988) Inorganic nitrogen utilization by assemblages of marine bacteria in seawater culture. Mar Ecol Prog Ser 50:147-150

Jørgensen NOG, Kroer N, Coffin RB, Yang XH, Lee C (1993) Dissolved free amino acids, combined amino acids, and DNA as sources of carbon and nitrogen to marine bacteria. Mar Ecol Prog Ser 98:135-148

Jørgensen NOG, Kroer N, Coffin RB, Hoch MP (1999) Relations between bacterial nitrogen metabolism and growth efficiency in an estuarine and an open-water ecosystem. Aquat Microb Ecol 18:247-261

Kanda J, Laws EA, Saino T, Hattori A (1987) An evaluation of isotope dilution from conventional data sets of ${ }^{15} \mathrm{~N}$ uptake experiments. J Plankton Res 9:79-90

Keil RG, Kirchman DL (1991) Contribution of dissolved free 
amino acids and ammonium to the nitrogen requirements of heterotrophic bacterioplankton. Mar Ecol Prog Ser 73: $1-10$

Kinniburgh J (1998) Physical and chemical characteristics. In: Attrill MJ (ed) A rehabilitated estuarine ecosystem. Chapman \& Hall, London, p 27-48

Kirchman DL (1994) The uptake of inorganic nutrients by heterotrophic bacteria. Microb Ecol 28:255-271

Kirchman DL, Wheeler P (1998) Uptake of ammonium and nitrate by heterotrophic bacteria and phytoplankton in the sub-Arctic Pacific. Deep-Sea Res I 45:347-365

Kirchman DL, Moss J, Keil RG (1992) Nitrate uptake by heterotrophic bacteria: does it change the f-ratio? Arch Hydrobiol 37:129-138

Kirchman DL, Ducklow HW, McCarthy JJ, Garside C (1994) Biomass and nitrogen uptake by heterotrophic bacteria during the spring phytoplankton bloom in the North Atlantic Ocean. Deep-Sea Res I 41:879-895

Koroleff (1983) Determination of urea. In: Grasshoff K, Erhardt M, Kremlink K (eds) Methods of seawater analysis. Verlag Chemie, Weinheim, p 158-162

Lee C, Hedges JI, Wakeham SG, Zhu N (1992) Effectiveness of various treatments in retarding microbial activity in sediment trap material and their effects on the collection of swimmers. Limnol Oceanogr 37:117-130

Lindroth P, Mopper K (1979) High performance liquid chromatographic determination of subpicomole amounts of amino acids by precolumn fluorescence derivatization with o-phthaldialdehyde. Anal Chem 51:1667-1674

Lipschutz F (1995) Nitrogen-specific uptake rates of marine phytoplankton isolated from natural populations of particles by flow cytometry. Mar Ecol Prog Ser 123:245-258

Lomas MW, Glibert PM (1999) Temperature regulation of nitrate uptake: a novel hypothesis about nitrate uptake and reduction in cool-water diatoms. Limnol Oceanogr 44: 556-572

McCarthy JJ, Taylor RW, Taft JL (1977) Nitrogenous nutrition of plankton of the Chesapeake Bay. 1. Nutrient availability and phytoplankton preference. Limnol Oceanogr 223: 996-1911

Middelburg JJ, Nieuwenhuize J (2000) Uptake of dissolved

Editorial responsibility: Otto Kinne (Editor),

Oldendorf/Luhe, Germany inorganic nitrogen in turbid, tidal estuaries. Mar Ecol Prog Ser 192:79-88

Middelburg JJ, Klaver G, Nieuwenhuize J, Wielemaker A, de Haas W, van der Nat JFWA (1996) Organic matter mineralization in intertidal sediments along an estuarine gradient. Mar Ecol Prog Ser 132:157-168

Nedwell DB, Jickells TD, Trimmer M, Sanders R (1999) Nutrients in estuaries. Adv Ecol Res 29:43-92

Nieuwenhuize J, Maas YEM, Middelburg JJ (1994) Rapid analysis of organic carbon and nitrogen in particulate materials. Mar Chem 44:217-224

Oremland RS, Capone DG (1988) Use of specific inhibitors in biogeochemistry and microbial ecology. Adv Microb Ecol 10:285-383

Palenik B, Morel FMM (1990) Amino acid utilization by marine phytoplankton: a novel mechanism. Limnol Oceanogr 35:260-269

Pennock JR (1987) Temporal and spatial variability in phytoplankton ammonium and nitrate uptake in Delaware estuary. Estuar Coast Shelf Sci 24:841-857

Riegman R, Flameling IA, Noordeloos AAM (1998) Size-fractionated uptake of ammonium, nitrate and urea and phytoplankton growth in the North Sea during spring 1994. Mar Ecol Prog Ser 173:85-94

Shaw PJ, Purdie DA, de Frietas PS, Rees AP, Joint I (1998) Nutrient uptake in a highly turbid estuary (the Humber, United Kingdom) and adjacent coastal waters. Estuaries 21:507-517

Stark JM, Hart SC (1997) High rates of nitrification and nitrate turnover in undisturbed coniferous forests. Nature 385: 61-64

Stolte W, Riegman R (1996) The relative preference index (RPI) for phytoplankton nitrogen use is only weakly related to physiological preference. J Plankton Res 18: 1041-1045

Underwood GJC, Kromkamp J (1999) Primary production by phytoplankton and microphytobenthos in estuaries. Adv Ecol Res 29:93-153

Wheeler PA, Kirchman DL (1986) Utilization of inorganic and organic nitrogen by bacteria in marine systems. Limnol Oceanogr 31:998-1009

Submitted: January 31, 2000; Accepted: March 24, 2000

Proofs received from author(s): August 24, 2000 